\title{
Some projects from the past
}

\section{São Paulo}

WHEN the first wave of oil price surges arrived in 1973, Brazil reacted with two new and massively expensive programmes to reduce dependence on energy imports. One was intended to provide electricity from nuclear power, the other to substitute sugar alcohol for petroleum. Both projects were creations of a military government which could exercise strong central control over resources. Fifteen years later, both projects are floundering as they face markets which demand a more rational allocation of resources.

Opposition to the nuclear programme was strong from the start. "It was very clear that nuclear energy for electricity production was a complete misconception," says University of São Paulo (USP) rector, José Goldemberg, a well-known critic of Brazil's nuclear plans, "seven billion dollars gone with little to show".

A small US reactor is in operation but the agreement signed with West Germany to build eight reactors has yet to create one operating plant. The programme, "was slowly delayed but never cancelled," says Goldemberg, "scientists opposed it because it involved very little technology transfer. Industrialists who lost opportunities because of support for the programme opposed it." Last week, West Germany extended the agreement with much reduced goals. But the situation may change again under a new president. Goldemberg believes that "in a democratic society it will become increasingly difficult to justify the expenditure against social programmes". The sugar alcohol programme appears very much more successful.

Four million of Brazil's 12.5 million vehicles run on alcohol produced from fermentation of sugar and massive reduc-

\section{Parallel secrets}

Fears that Brazil is intending to develop nuclear weapons in secret are fading with the return of democracy.

In 1987, after the disppearance of the military regime, a secret 'parallel' nuclear programme emerged with the announcement by President José Sarney that the navy had succeeded in low-level enrichment of uranium fuel. The work was carried out at the Institute for Energy and Nuclear Research (IPEN), adjacent to the USP campus.

The aim of the programme is not a bomb, but fuel for a nuclear-powered submarine. Although Brazil has no enemies and the expense of developing nuclear submarines seems superfluous, the offical reply is that the project will take 20 years and by then Brazil will be a great power. The navy was much impressed by the performance of nuclear submarines during the Falklands conflict. tions in petroleum imports have been achieved. But the programme is in serious economic and political trouble. Brazil has found large oil reserves of its own. Sugar alcohol is proving more expensive to produce than petroleum, the distilleries are producing huge quantities of polluted water, and subsidies for sugar-cane growing distort local economies by encouraging farmers to grow cane even when vegetables are in short supply.

These, at least are the arguments advanced by the state petroleum industry, which wants to see petrol roll back some of alcohol's advance. With the backing of the Ministry of Mines and Energy, the petroleum industry has scored well in the media war. The sugar alcohol industry, backed by the Ministry of Industry and Commerce, is in retreat but it too claims that subsidies disguise the true state of the petroleum industry. The battle of the subsidies will be fought between the two ministries under the new president and in the minds of consumers, who must decide which kind of car to buy.

One factor in the battle is the scope for improvement in sugar alcohol production. Waste treatment is already possible and biotechnology may offer much more. Little sustained effort has gone into the improvement of yeasts. Genetic engineering can permit new substrates to be used, such as starch which yeast cannot normally degrade. In a clever piece of engineering, Ana Clara Schenberg at USP has already constructed yeast strains carrying $\alpha$-amylase genes from mouse, plus other yeast genes introduced by conventional genetics and shown the new strain can produce ethanol directly from starch. While the project is at the laboratory stage, it suggests that it is too soon to begin writing off sugar alcohol.

As the 'parallel' programme went public, demands increased for greater accountability of the military's activities. The new constitution prohibits the development of nuclear weapons and gives Congress control over the nuclear energy programme. But the constitution left possible the development of 'peaceful' nuclear explosives. The first steps towards civilian control came last year when the government established a Superior Council for Nuclear Energy as an advisory board to the president. Goldemberg was one of three civilian scientists on the council, which includes 17 ministers. Although the meetings are not frequent, Goldemberg says that "the president attends and it is now very difficult to do anything under cover".

Next step could be a congressional committee with oversight of military programmes. Brazil would then be close to the certainty that the submarine programme could not be diverted towards manufacture of a bomb.

\section{Rio de Janeiro}

IF new styles of collaboration between the universities and industry are what is needed to boost investment in science, then the Federal University of Rio de Janeiro (UFRJ)'s island may be the place to look for future trends. Here Antonio Paes de Carvalho has confidently launched a new biotechnology venture, Bio-Rio, which links industry, the Oswaldo Cruz Foundation and the university. Within ten years, Paes de Carvalho confidently predicts there will be 70 companies here, employing some 4,500 people and enjoying $\$ 250$ million in sales.

Paes de Carvalho is a cardiac electrophysiologist, an unusual skill from which to move into biotechnology. But in 1980 , he says, he was director of the Institute of Biophysics at UFRJ and became "worried about the financing of research". As there were experts in tissue culture and molecular biology in the institute, Paes de Carvalho thought biotechnology might be a good bet.

So with the belief that "you have to do things yourself", he set up a non-governmental, biotechnology foundation close by. The foundation will operate central research facilities and allocate surrounding land, at a nominal cost, to private enterprise. The central facility will offer specialized services (for example, peptide and nucleotide sequencing and synthesis) and provide 'incubator' space where projects can be developed.

In October the central laboratory facility was being carved out of the vast kitchen (conveniently complete with cold storage rooms) of an abandoned university cafeteria. This month, the first two companies are moving into their incubator space.

There are other biotechnology intiatives elsewhere but none based on direct interaction between industry and university. "The biggest fight," says Paes de Carvalho, "is to convince the university that this kind of industrial proximity is OK'. The university authorities at first rejected the project, but were eventually persuaded with help from the rector - as he was a communist he apparently could not be accused of selling out to capitalists.

The government has invested \$3 million in Bio-Rio, and industry another $\$ 1$ million. Paes de Carvalho expects industry to provide another $\$ 100$ million over five years, encouraged by big incentives from the National Development Bank. Critics say the plan's weakness is the shortage of qualified researchers, most of then in universities and without interest in links to industry.

But Paes de Carvalho believes that he can engineer the interaction between university and industry so that it will be painless for researchers and not threaten basic research. 